\title{
CIRJE-F-103 \\ Apparel Distribution: \\ Inter-firm Contracting and Intra-firm Organization
}

\author{
Yoshiro Miwa \\ University of Tokyo \\ J. Mark Ramseyer \\ Harvard University / CIRJE \\ February 2001
}

Discussion Papers are a series of manuscripts in their draft form. They are not intended for circulation or distribution except as indicated by the author. For that reason Discussion Papers may not be reproduced or distributed without the written consent of the author. 
JEL: D3, L6, L8

Forthcoming in:

Distribution in Japan (Oxford University Press).

\title{
Chapter 3
}

Apparel Distribution:

Inter-firm Contracting and Intra-firm Organization

\author{
by \\ Yoshiro MIWA \\ University of Tokyo \\ and

\section{J. Mark RAMSEYER \\ Harvard University}

\begin{abstract}
Prepared for a forthcoming book on the distribution sector in Japan, this essay introduces the distribution network in the apparel industry. We note the varying patterns of cross-market contracting and intra-firm organization in the industry, and trace the economizing logic involved. More specifically, we show how the decision at the firm level of whether to integrate wholesale, retail and production depends crucially on an informational and incentive-based logic, and how that logic is in turn driven by patterns of consumer demand.
\end{abstract}

Professor of Economics, University of Tokyo (Miwa), and Mitsubishi Professor of Japanese Legal Studies, Harvard University (Ramseyer; on leave, University of Tokyo). We gratefully acknowledge the helpful comments and suggestions of Mark West, and the generous financial assistance of the John M. Olin Program in Law, Economics \& Business at the Harvard Law School, the Center for the International Research on the Japanese Economy at the University of Tokyo, and the Sloan Foundation. 
"They're all the same. None of 'em are exciting." The sale of men's business suits had fallen since 1992 in Japan and that, apparently, was how one industry executive explained it (Senken, 1999: 132). He was surely right, of course, though the explanation bordered on the apocryphal economist's reason for the long line at the movie theater: the price was too low.

For fifty years, charcoal (or navy) suits had been the uniform of choice (oxymoronic to be sure) for Japanese men. ${ }^{\text {D }}$ Before World War II, the country had remained heavily agricultural, and had had a manufacturing comparative advantage primarily in unskilled factory work. Come 1950, matters changed. Over the next two decades, in droves young men abandoned the farm for the city, the shop for the office, and coarse cotton uniforms for worsted wool suits. From 1950 to 1960 to 1970 to 1980, the population in agriculture fell from 16 million to 13 to 9 to 5 (Nihon tokei, 1987: I, tab. 3-7). Over the same period, the population in white-collar jobs (men in professional, technical, managerial, official, or clerical posts) climbed from 4.1 (in 1952) to 5.3 to 7.0 to 8.7 million (id., at tab. 3-11).

To this work, the new "salary man" -- as he called himself -- wore a wool suit. He sported a blue (not red) silk tie, and a white (not blue) cotton shirt with a straight (not button-down) collar. He wore black (not brown) shoes and belt. Cuff-links were a personal option.

In turn, the new salary man obtained his suits through a process that illustrates the organization of distribution in one sector of the apparel industry. His well-heeled fiancée found her Parisian dress in a process that illustrates it in another. Together, the two processes show both how distributional patterns reflect the direction and volatility of underlying consumer preferences, and how a change in those preferences will shift the structure of distribution.

The industry itself is huge. By government estimates, the Japanese apparel industry had some 20 trillion yen in mid-1990s sales and employed 2.8 million workers. 2 Yet despite that size, observers (whether U.S. critics or Japanese bureaucrats) routinely characterize it as inefficient, exclusionary, and opaque. ${ }^{3}$ From raw cotton or wool to retail shelves, a garment traverses a long chain of firms and brokers. Within that chain, critics argue, the firms and brokers contract by medieval customary practices that only loosely track the terms of any documents they exchange.

In this chapter, we use standard economic theory (though we focus on the empirics and keep citations to theory at a minimum) to unravel the informational and risk-bearing rationale for these distributional patterns. Largely, we find that the firms involved adopt patterns that allocate risks to the firms with the incentives and information necessary to bear risk most cheaply. Often, they also accomplish what one might have thought core intra-firm functions through cross-market transactions.

\footnotetext{
${ }^{1}$ When not otherwise noted, most of the current data are from widely available sources such as the Toyo keizai kaisha shikiho.

${ }^{2}$ Matsuo (1999: 2). The Table 3 figures are for production only.

${ }^{3}$ Even the industry itself takes that position at times. See Sen'i kogyo (1991). That the industry is not inefficient or exclusionary is suggested, however, by the fact that several of the "problems" identied by the industry involve discounting and other forms of price competition. $\underline{I d}$.
} 
Whether they locate those functions within a firm or across markets similarly depends, we conclude, on a least-cost-avoider logic.

All told, three further points follow. First, in the context of a competitive retail market the informational logic to the distributional practices illustrates their essential efficiency. That efficiency, in turn, is reflected in the absence of large total distribution markups. Second, the ease with which parties can shift distribution strategies illustrates their non-exclusivity. That non-exclusivity is reflected as well in the speed with which apparel imports increased when exchange rates changed in the 1980s. What then of the pervasive claims of opacity from U.S. lawyers and legally trained Japanese bureaucrats? Given the straightforward economic logic to the distribution patterns, these claims probably just demonstrate (as if we needed another demonstration) the essential blindness of legal education.

We begin with a lengthy description of the distribution process in the apparel industry itself. We start with one pole of the industry: the conservative world of men's business suits (Section 1.1.1). This is an exceptional segment of the industry, albeit exceptional in a way that illustrates how consumer preferences and technological change can cause massive changes in distributional practices. From this sector, we turn to more mainstream segments, and study the traditional distribution practices for high-end (Section 1.1.2) and middle-market (Section 1.2) apparel. Using standard law-\&-economic theory, we explore the ties between retailing and production (Section 2), and the impact of several recent changes in distribution (Section 3). We close by outlining the implications all this poses for the efficiency, exclusivity, and opacity of the industry (Section 4).

\section{APPAREL RETAILING}

\subsection{The High-End}

1.1.1. Men's business suits. To wear to their new white-collar jobs, post-war Japanese men bought business suits in enormous numbers. On a population of 105 million, in 1971 Japanese bought 8.6 million suits and 5.0 million sports coats; on a population of 124 million in 1990, they bought 12.2 million suits and 7.1 million sports coats (Miwa, 1994: 34; Nihon tokei, 2000: 2). Where Japanese men bought 13.9 million suits in 1988, Americans (with roughly twice the population) bought 15.5 million (Miwa, 1994: 35). For these suits, Japanese men in the early post-war years paid dearly. In 1960, for a new bank clerk a tailor-made suit cost nearly two-months' salary $(i d$.$) .$

1.1.2. Department stores. Introduction. To buy these suits, Japanese men went to "department stores." What Rodeo Drive is to Los Angeles and North Michigan Avenue to Chicago, department stores have been to post-war Tokyo. By tradition, suits were not sold through tailors, and the highest status labels did not maintain boutique shops. Instead, both suits and fashion went through department stores. A gentleman looking for a new suit did not go to a local haberdasher. He went to a department store. A lady trolling for the latest from Paris or Milan did not browse through Hermes or Ferragamo shops. She combed the department stores.

${ }^{4}$ In 1998 department stores earned 41.2 percent of their sales from clothing generally, and 9.1 percent from men's clothing. They earned 24.8 percent of their sales from women's clothing, 3.2 percent from children's clothing, and 4.1 percent for other clothing items (Depaato, 1999: 93). In 1990, Japanese spent about 4.3 trillion yen on apparel. Of this, they spent 1.5 billion (36 percent) on men's apparel, 2.2 billion (50 percent on women's apparel, and the remainder on children's apparel (Nihon sen'i, 1992: 97-100). 
Genesis. The oldest of these department stores traced their roots to operations antedating the 1868 Meiji Restoration. The venerable Mitsukoshi, for example, began as a Tokyo (then-Edo) draper in the 17th century. Today, it stands at the apex of the retail status hierarchy (see sales at Table 3.1.B). The Matsuzakaya (founded 1910), Takashimaya (1919), Matsuya (1919), and Daimaru (1920) chains all began pre-war as well.

Despite these antecedents, the explosive growth in department stores dates from the 1950s. From 1948 to 1958, department store floor area jumped 160 percent; from 1959 to 1969, it climbed another 65 percent. From 1948 to 1969, the number of department store employees increased from 30,000 to 130,000 (Depaato, 41). Mitsukoshi may have started in the 1600s, but the Seibu, Tobu, Tokyu, Hankyu, Hanshin, Keio, Odakyu, and Kintetsu stores are all part of private railroad networks serving the bedroom suburbs that grew so explosively post-war. Osaka-based Hankyu had one full-scale department store before the war. Since then, it has built eight more (Hankyu, 1998). Of the current 28 central Tokyo department stores, only 9 were open by 1950 . By 1970, 21 were (Table 3.2).

Essentially, the department stores developed in tandem with the new patterns of consumer behavior that blossomed in the 1950s and 1960s. Many of these phenomena came from the West, and for many the department stores were the ports of entry. The Takashimaya department store brought Pierre Cardin to Japan, while Daimaru brought Christian Dior (Nihon sen'i, 1992: 113). The Seibu stores singlehandedly brought to Japan Yves Saint Laurent, Hermes, Van Clef and Arpels -- and, more recently, Polo Ralph Lauren and Armani (Hashimoto and Koyama, 1991: 430).

Today, department stores dominate high-end shopping. Even during a bad recession (as in mid-October 2000), a visit to one is not an event lightly undertaken by a college professor without substantial consulting income or textbook sales. Take the Ikebukuro Tobu. With floor space of 85,944 square meters, by size it is the second largest in Tokyo (see Table 3.2). By status, it falls somewhere in the middle of the pack.

Tobu has two basement levels, and nine floors above ground. On one basement floor it sells upscale groceries, along with the usual stratospheric items (purchased primarily as gifts) that the Tokyo guidebooks love to detail: apples and Asian pears at 800 yen each (the exchange rate was 108 yen $\$$ ), a matsutake mushroom at 9,000 yen (for one mushroom), tuna at 1,598 yen/100g (\$67/lb.), and Japanese beef at 3,333 yen $/ 100 \mathrm{~g}(\$ 140 / \mathrm{lb}$.). It also offers reasonable if nice deli items and box lunches: closest to the subway entrance, it places an enormous array of affordable take-out dinners for busy middle-class families. On the second basement floor it stocks additional gift food items: pastries, boxed cookies with German and French names, traditional Japanese food gifts, Godiva chocolates at 300 yen a truffle.

Above ground, Tobu maintains a layout reflecting both its variety and its dependence on a female clientele. It has one floor for cosmetics; one for women's accessories and shoes (Gucci, Versace, Celine, and so forth); two floors for women's clothing and jewelry (including Anne Klein, Calvin Klein, Issei Miyake); one floor for men's clothing and shoes; one for home furnishings; one for children's toys, books, and office supplies (like a 120,000 yen Waterman pen); one for sporting goods; and one for kimonos. Above all this, it carries seven floors of restaurants.

Contractual practice. "Gone today, here tomorrow," Alfred Knopf allegedly (and perhaps apocryphally) observed as he watched the delivery trucks leave his 
publishing company warehouse. In much the same vein, Japanese department stores buy apparel with a right to return. Already in the mid-1950s, apparel makers began offering the department stores this right. Junzo Kashiyama, founder of the giant Onward Kashiyama firm, introduced the arrangement in 1953 (see Table 3.1.A; Nikkei ryutsu, 1993: ch. 15). Before then, department stores had taken title to the goods with no right of return. As a result, found Kashiyama, they regularly bought insufficient stock and ran out of merchandise before the end of the season. Rather than have unsold stock, they bought insufficient quantities.

At root, the department store buyers did not know the volatile new market for western-style clothing well enough to make sensible decisions. Founded in 1947, Onward Kashiyama was new at the game too, but as a national specialist it knew more than the department stores. Given his firm's superior market expertise, Kashiyama promised to take back anything unsold. In exchange, he ensured that he did not lose sales for lack of department store stock.

To handle the resulting business risk, Kashiyama took two steps. First, he kept control over price (hence the customary resale price maintenance in this sector). Second, he sent employees to the stores daily to monitor sales. If an item moved slowly, he either withdrew it from the store or lowered its price. If it sold quickly, he shipped more.

Not only did these seconded employees give Onward Kashiyama immediate information about which products sold most quickly. They also talked directly and regularly to the firm's ultimate clientele. Instead of learning indirectly what department store buyers thought consumers wanted to buy, Kashiyama employees could hear from consumers themselves.

Through this arrangement, Kashiyama effectively shifted many of what one might consider retailing functions to the apparel maker. Although the department store remained the retailer in form, in significant ways the apparel maker became the retailer in substance. It decided price, controlled stock, provided some of the sales force, and paid the department store what was effectively a sales-based floor rental charge.

Given that apparel makers generally knew the market better than the department stores, Kashiyama's arrangement soon became the industry norm. The actual contractual terms varied, but generally took one of three forms. Sometimes, the department store obtained title to the goods but kept a customary right to return unsold merchandise at full price. Sometimes it took title but retained a contractual right to return it. And sometimes it took the goods on consignment. In each case, it implicitly paid a premium for the return right. 
Table 3.1: The Apparel Industry

A. Top Apparel Makers, by Sales (billion yen)

\begin{tabular}{lrlrll} 
Total Apparel & Women's Apparel & Men's Apparel \\
\hline & & & & & \\
Renown & 199 & Itokin & 124 & Onward K & 89 \\
Onward K & 168 & World & 110 & San'yo S & 47 \\
Itokin & 135 & Renown & 91 & D' urban & 46 \\
San'yo S & 130 & San'yo S & 79 & Renown & 42 \\
Gunze & 127 & Onward K & 74 & Minoya & 34
\end{tabular}

Notes: All figures are for fiscal 1995, except San'yo shokai and Durbin, which are for calendar 1994. shokai. Onward $\mathrm{K}=$ Onward Kashiyama; San'yo $\mathrm{S}=$ San'yo

B. Top Apparel Retail Chains, by Sales (billion yen)

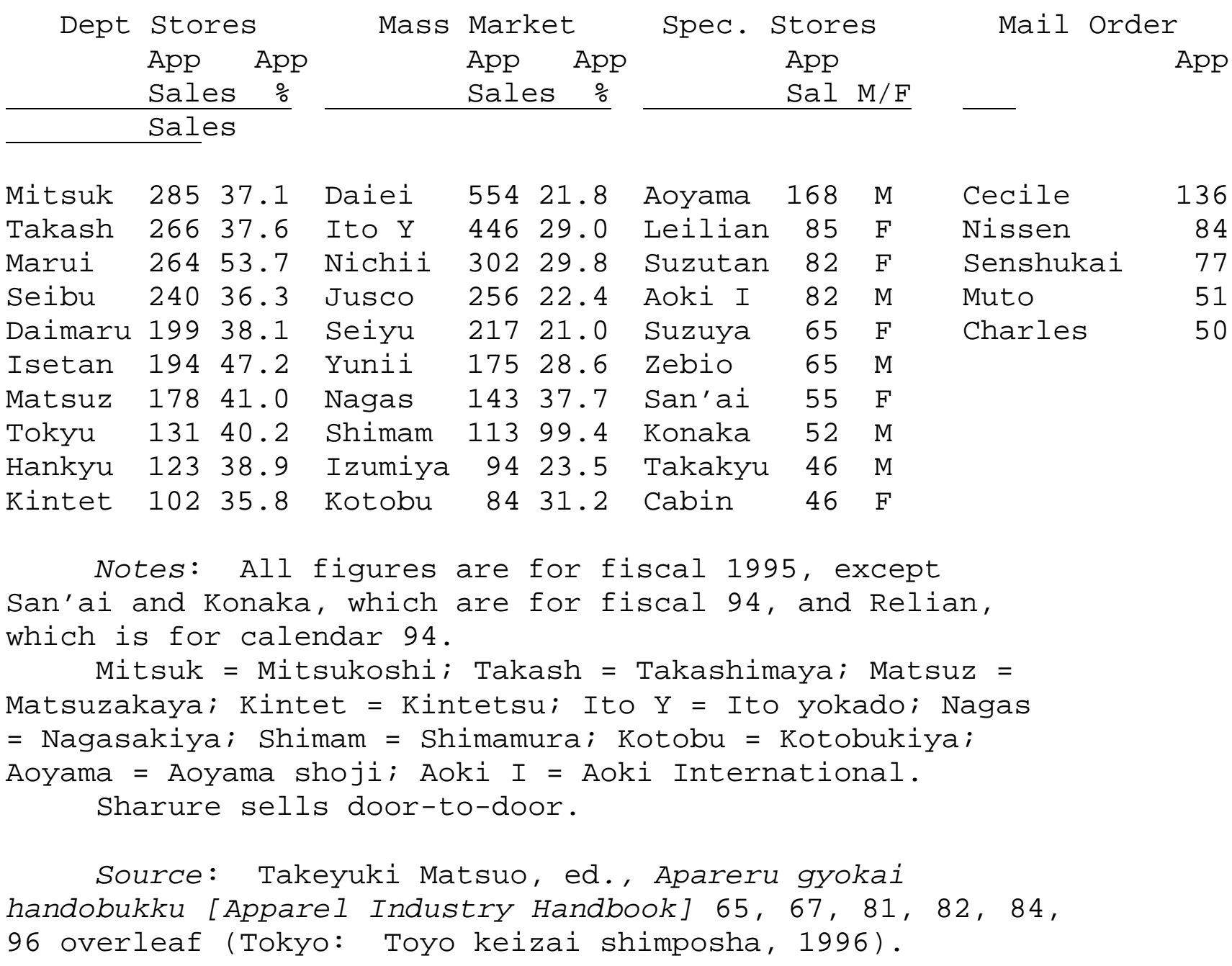


Table 3.2: Central Tokyo Department Stores, 1998

\begin{tabular}{|c|c|c|c|}
\hline & $\begin{array}{l}\text { Sales area } \\
\text { (sq. meter) }\end{array}$ & $\begin{array}{c}\text { Sales } \\
\text { (billion yen) }\end{array}$ & Opened \\
\hline Mitsukoshi (Nihon bashi) & 92,095 & 284.6 & 1673 \\
\hline Tobu (Ikebukuro) & 85,944 & 149.7 & 1962 \\
\hline Tokyu (Shibuya) & 74,081 & 148.6 & 1967 \\
\hline Seibu (Ikebukuro) & 73,814 & 277.7 & 1940 \\
\hline Isetan (Shinjuku) & 62,511 & 250.1 & 1933 \\
\hline Odakyu (Shinjuku) & 59,858 & 135.1 & 1962 \\
\hline Takashimaya (Shinjuku) & 56,100 & 75.3 & 1996 \\
\hline Takashimaya (Nihon bashi) & 50,687 & 206.3 & 1933 \\
\hline Seibu (Shibuya) & 43,236 & 62.3 & 1968 \\
\hline Matsuzakaya (Ueno) & 41,828 & 80.4 & 1768 \\
\hline Keio (Shinjuku) & 41,292 & 106.0 & 1964 \\
\hline Tokyu (Nihon bashi) & 35,223 & 31.3 & \\
\hline Sogo (Kinshicho) & 35,160 & 15.0 & 1997 \\
\hline Mitsukoshi (Shinjuku) & 34,395 & 46.5 & 1929 \\
\hline Daimaru (Yaesu) & 32,631 & 71.6 & 1954 \\
\hline Matsuya (Ginza) & 31,576 & 64.7 & 1925 \\
\hline Takashimaya (Tamagawa) & 25,767 & 43.8 & 1969 \\
\hline Matsuzakaya (Ginza) & 25,467 & 26.8 & 1954 \\
\hline Mitsukoshi (Ikebukuro) & 25,026 & 34.3 & 1957 \\
\hline Mitsukoshi (Ginza) & 23,350 & 65.7 & 1930 \\
\hline Matsuya (Asakusa) & 18,908 & 19.8 & 1931 \\
\hline Mitsukoshi (Ebisu) & 17,893 & & 1994 \\
\hline Printemps (Ginza) & 16,541 & 28.8 & 1984 \\
\hline Seibu (Yurakucho) & 15,581 & 19.4 & 1984 \\
\hline Sogo (Ginza) & 15,275 & 17.0 & 1957 \\
\hline Hankyu (Shinagawa) & 15,068 & 11.6 & 1953 \\
\hline Hankyu (Yurakucho) & 14,721 & 18.9 & 1984 \\
\hline Hankyu (Sukiyabashi) & 7,017 & 7.5 & 1956 \\
\hline
\end{tabular}

Source: Depaato nyusu sha, ed., Hyakkaten chosa nenkan [Department Store Survey Annual] (Tokyo: Depaato nyusu sha, 1999). 


\subsection{The Middle-market:}

If Japanese browse the department stores when they want something especially "nice," they frequent the mass-market chains for their more quotidian needs. Sometimes translated "general merchandise stores," sometimes as "super stores," these outlets are what Americans would probably call middle-market department stores. Most date from the 1960s. Positioned variously in the enormous expanse between Wal-mart and Sachs, they are large stores that sell a wide variety of merchandise (about 30 percent of it apparel). Some, like Daiei, hang their appeal on low prices. Others, like Ito-Yokado, hang it on good value at a slightly higher price. But each of the three largest chains sells more apparel than the largest department store (Table 3.1.B).

Make no mistake -- these are not discount stores. There are discount apparel outlets in Japan, but Daiei and Ito Yokado are not it. Take one ordinary Ito Yokado in the Tokyo suburb of Higashi-kurume. It had three sales floors with total sales space of 14,000 square meters, and 1998 sales (for this store alone) of 14 billion yen. Above those three floors, it had five stories for parking. It devoted half the first floor to food-stuffs, but none of it for gifts. As of mid-October 2000, the most expensive apple was 200 yen, Asian pear 250, matsutake mushroom 1,580, tuna 278 yen/100g, and beef $980 \mathrm{yen} / 100 \mathrm{~g}$. On the same day, a determinedly price-sensitive housewife in the neighborhood could have found apples for 60 yen and Asian pears for 100. She could not have done much better on the tuna, but could have bought imported U.S. beef at 128 yen/100g. A determinedly price-sensitive housewife would have skipped the matsutake and used shiitake mushrooms instead.

On the rest of the first floor, the store stocked bags, shoes, women's apparel, cosmetics, jewelry, and assorted household items. It had more apparel on the second floor (including men's and children's). It carried additional household items, toys, books, sporting goods (even bicycles), watches, and restaurants on the third. A consumer could find a 1.5 million yen diamond ring, but not many. A consumer could find Vuitton, Celine, Prada, and Fendi hand bags, but the store gave more space to American Tourister. For shoes, a consumer would mostly have found running shoes and nondescript brands like Regal.

Ito Yokado and Tobu both carry apparel, but not all apparel is equal. In large part, stores like Ito Yokado sell goods that show the greatest price sensitivity, and about which consumers can most easily gauge quality. Underwear is perhaps the clearest example, and constitutes a major part of the apparel sold at Ito Yokado. Consistent with its emphasis on price-sensitive goods, the store also carries a large assortment of children's clothing.

This stratification by product mix is clearest at true discount stores like Shimamura. With 92 outlets, the chain had fiscal 2000 sales of 205 billion yen. Of those sales, 23 percent were underwear and 28 percent sleepwear. Consider one outlet, perhaps a mile from the Ito Yokado above. Where Ito Yokado was clean and spiffy, Shimamura was dirty and unkempt. Racks and tables of clothes stood in elaborate disarray, while half-opened boxes of stock blocked the aisles. Where Ito-Yokado offered courteous staff (if fewer than at Tobu) ready and able to restock and rearrange,

\footnotetext{
${ }^{5}$ Underwear is also a significant segment of the industry. In 1990, Japanese spent 4 trillion yen on apparel (excluding shoes). Of this, they spent 469 billion (11.6 percent) on underwear and sleep wear. By contrast men spent only 441 billion on suits, jackets, and tuxedos (Nihon, sen'i, 1992: 97 100).
} 
the harassed few workers at Shimamura had all they could do to keep the cash registers running.

But it was cheap -- oh, so cheap: fleece pullovers for 900 yen, wool sweaters for 1,900, dress shirts at 1,300 (with some on sale at 500 to 900), dress slacks at 1,900, belts at 400 to 1,500 , and silk ties at 900 to 1,900 . Underwear and socks it carried in all sorts of brands. In addition to a wide variety of Japanese brands by firms like Gunze, it had such foreign brands as BVD (by Fukusuke, made in Japan), Lee (by Naigai, made in Japan), and Champion (by Fukusuke, made in Vietnam).

\section{PRODUCTION}

\subsection{Introduction}

So far, this discussion presupposes that there are firms that manufacture garments -- firms one could sensibly call "apparel makers." Given that consumers do buy apparel made by firms, of course, there must be firms that make apparel. Yet in a curious sense this is an industry without manufacturers. Instead, it is an industry where an enormous number and variety of firms contract across markets to produce the merchandise collectively.

\subsection{Thread Production}

To see this, begin with the organization of production (we include a much abridged summary in Figure 3.1). Other than synthetics, the industry mostly imported its raw materials -- in 1997, 185 billion yen's worth. A total of 913 establishments (not all of them separate firms) with 8,700 workers imported this material.

Traditionally, these importers would have sent the wool or raw cotton to a Japanese spinning firm. The firms dominated pre-war Japapese manufacturing, and even today include 540 establishments with 25,700 workers. ${ }^{7}$ Often they function as the principal fabric maker, coordinating production among the many participants. Given their high labor costs, however, foreign firms compete fiercely for the work: in 1997, foreign spinners shipped 193 billion yen's worth of thread and yarn to Japan (see Table 3.3; Figure 3.2).

Thread brokers (922 establishments with 6,600 workers) bought the thread or yarn from the spinning firms, and sent it to firms that finished and sometimes dyed it (5,480 establishments, 23,600 workers). Depending on the material, the thread or yarn (perhaps again through a broker) then went either to a weaving or to a knitting firm (31,800 establishments, 169,300 workers). After producing the fabric, that firm in turn sold it to a fabric wholesaler $(6,005$ establishments, 52,900 workers). As necessary, a wholesaler might send the fabric to a print shop (6,305 establishments, 75,200 workers). Given labor costs foreign firms compete at this stage too: in 1997, foreign firms shipped fabric worth 218 billion yen.

\footnotetext{
${ }^{6}$ Unless otherwise indicated, the figures in this discussion are from Senken (1999: 149), for 1997.

${ }^{7}$ Synthetic fiber manufacturers operated bigger factories -- 94 establishments with 20,800 workers.
} 


\section{Figure 3.1: Apparel Production}

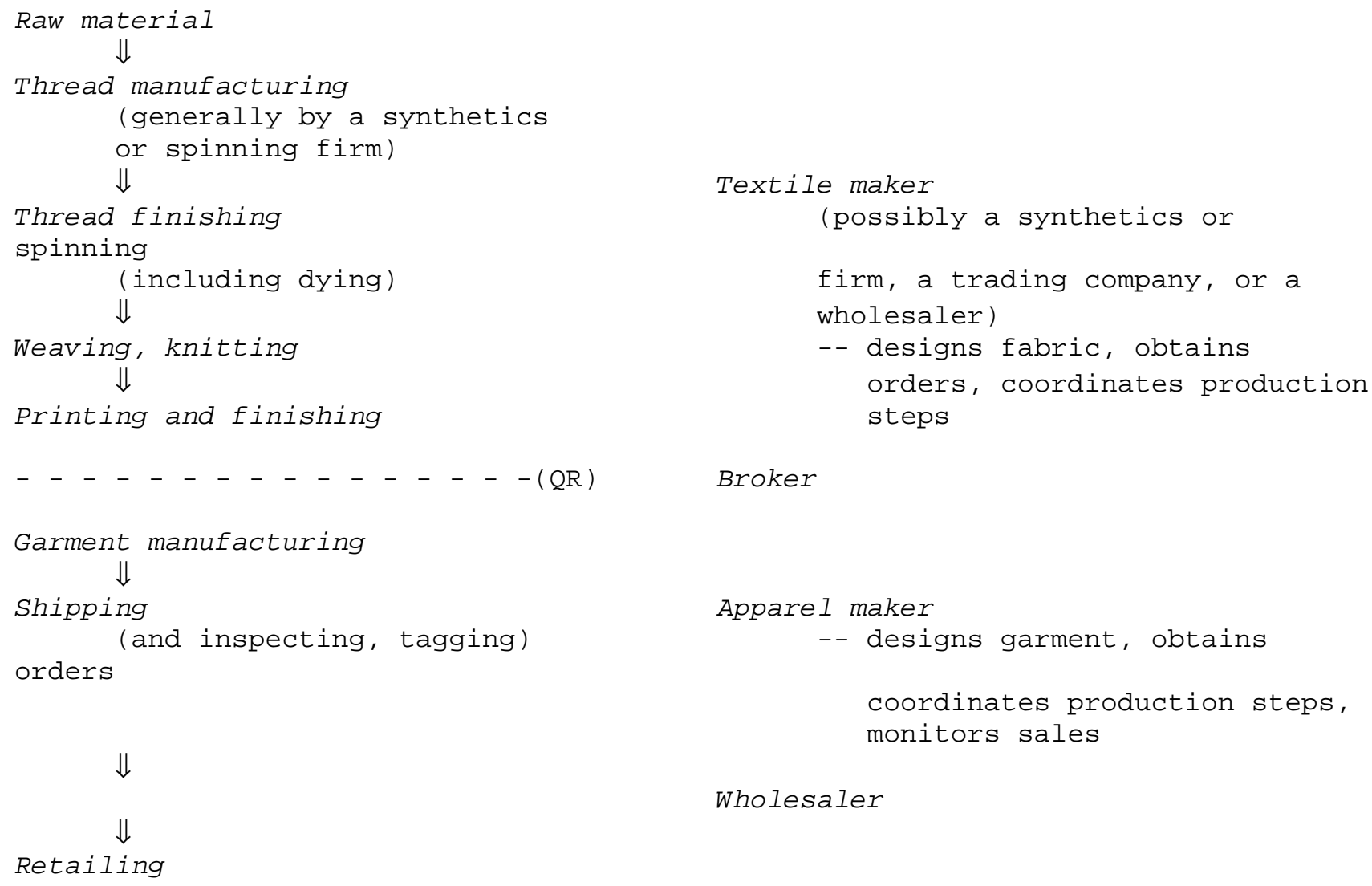

Wholesaler

Retailing

Source: Senken shimbun sha, ed., Yoku wakaru apareru gyokai [Easy to Understand -- The Apparel Industry] 66-67 (Tokyo: Nihon jitsugyo shuppan sha, rev. ed., 1999), as modified. 
Table 3.3: World Apparel Production

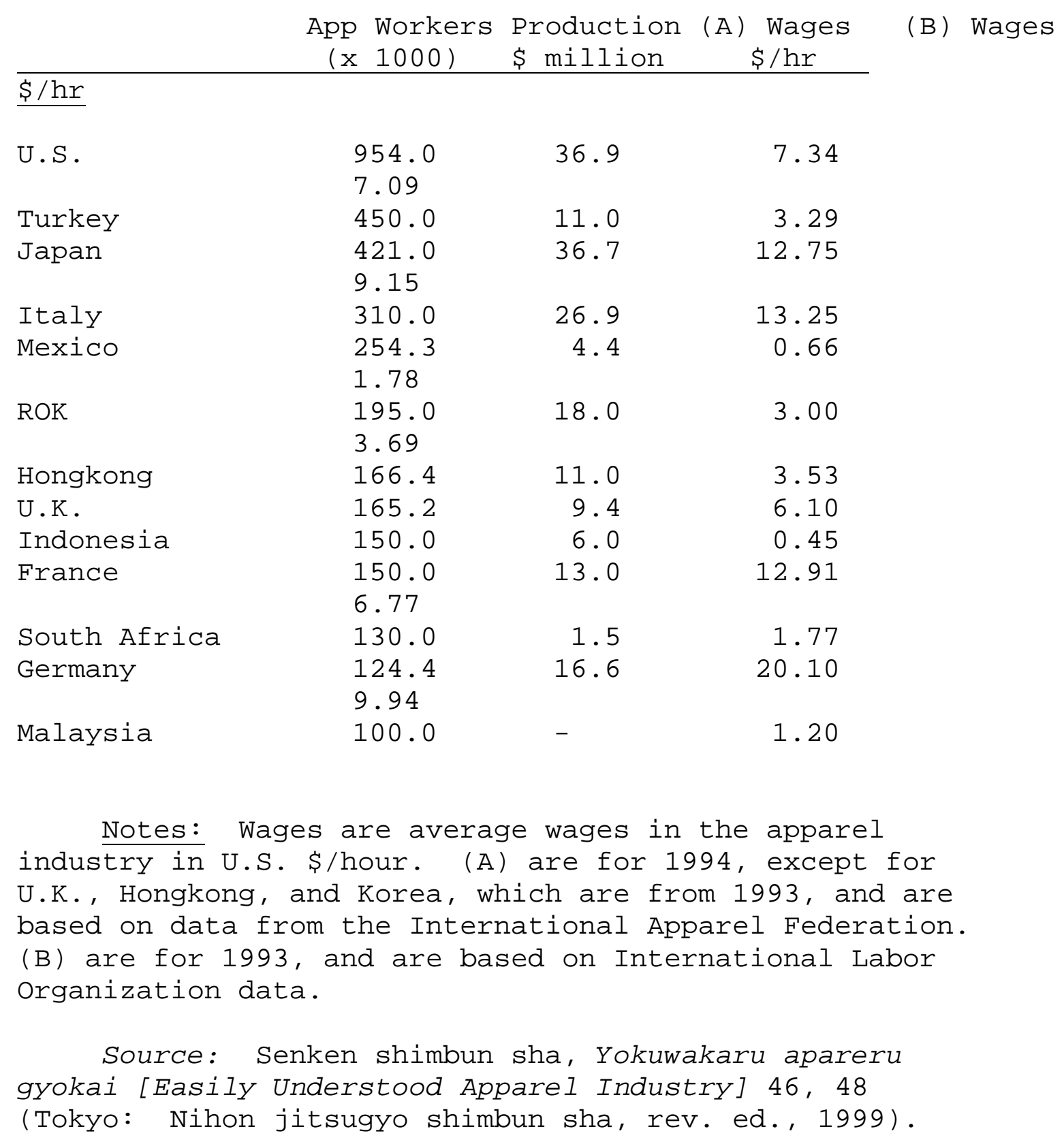


Figure 1.2: Textile Imports, by Country

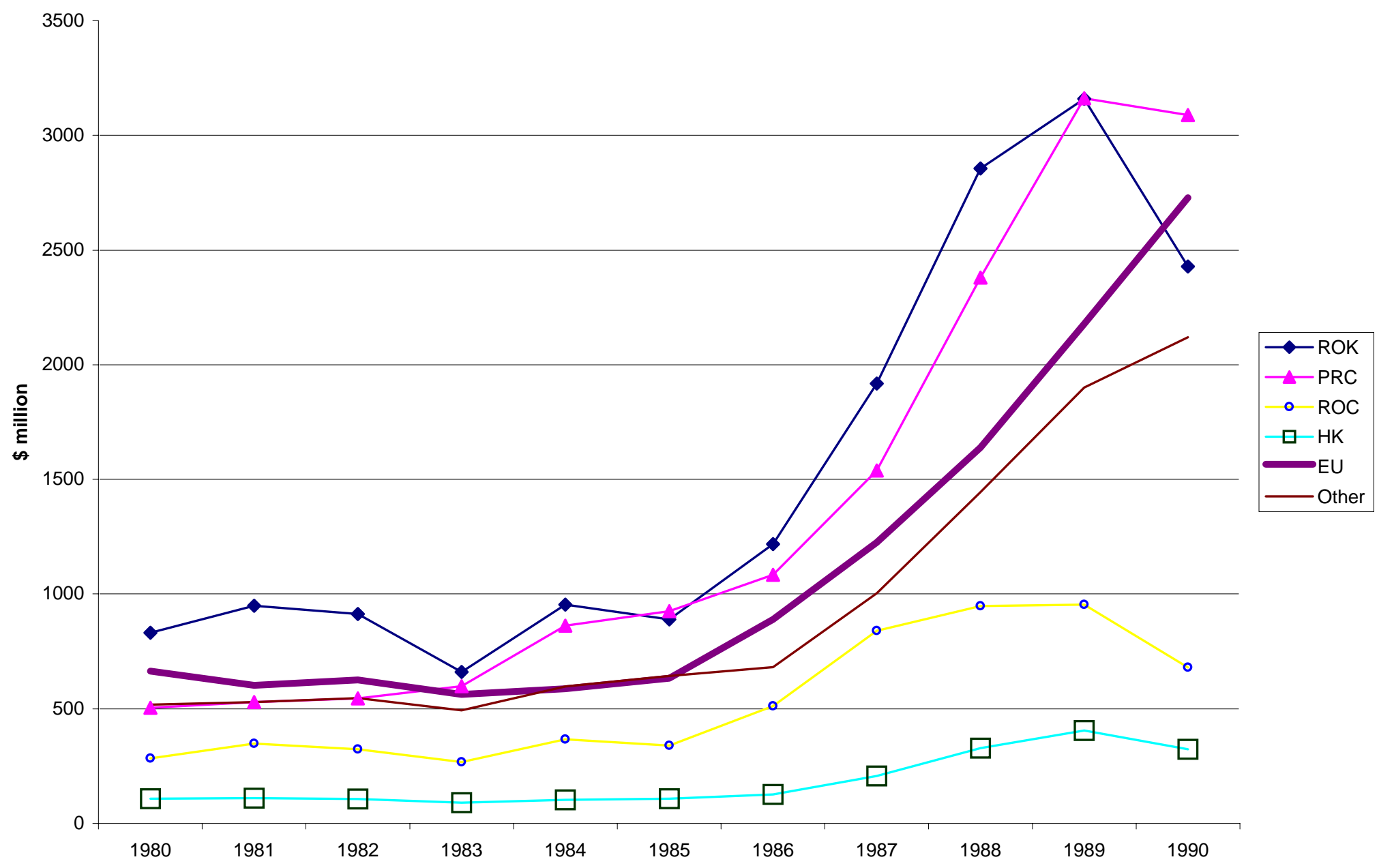

Source: Nihon sen'i shimbun sha, ed., Sen'i fasshon nenkan [Textiles, Fashion Annual] (Tokyo: Nihon sen'i shimbun sha, 1992). 


\subsection{The Apparel Maker}

Enter the apparel maker. It might design a garment itself. Or it might approach a designer for a new garment (the famous designers seldom maintain substantial manufacturing capacities of their own). It might place one of its house brands on the garment. Or it might pick from among the brands it licensed from other (perhaps foreign) firms. ${ }^{8}$

The apparel maker might manufacture the garment in house. Some do have modest manufacturing capacity. Usually, though, it will approach independent factories for production on an as-needed basis (50,890 establishments, 566,700 workers). It will keep almost no fabric or thread in stock, but buy it instead through brokers.

Upon receiving an apparel maker's order, a factory will buy printed cloth from a wholesaler and construct the garment. The apparel maker will take delivery, and ship it either to a retailer directly or to a garment wholesaler $(23,200$ establishments, 286,800 workers). In 1997, these wholesalers handled domestic garments worth 16,102 billion yen. Additionally, they imported garments worth another 2,298 billion, and exported 223 billion. Of the retailers, department stores (2,364 establishments, 156,800 workers) handled 6,616 billion yen's worth of merchandise. The other outlets (183,633 establishments, 644,524 workers; as noted later, this excludes convenience stores) handled 11,795 billion yen's worth.

That wholesalers (or brokers) play such a large part in the apparel industry reflects the division of labor into very small operations. For these small firms, the wholesalers provide information about the market, economize on search costs for trading partners, bear risk, and sometimes provide finance (Itoh, 1994: 22-23). When one of the parties is large (a spinning firm, for example) that firm will often by-pass the wholesaler. Indeed, the largest spinning firms had already integrated forward into weaving before the Second world War (Miwa and Ramseyer, 2000b). As all of this should make clear, however, in most cases the apparel maker is just another wholesaler. In effect, it is simply a hub that coordinates the final half of the production process.

\section{NEW CONTRACTUAL ARRANGEMENTS}

\subsection{Business Suits}

As labor costs in Japan rose after the war, apparel makers steadily improved the technology for ready-made suits. Back in 1960, over half the suits sold in Japan had been made to order. From 1970 to 1980 to 1989, that fraction fell from 39 percent to 12 percent to 6 percent (Miwa, 1994: 34).

In turn, the shift to ready-made suits reduced the comparative advantage to department stores in the market for business suits. When selling suits, the department stores had bonded the skills of their tailors through their large reputational capital. After all, consumers saw business suits as a major capital investment, but could gauge construction quality only ex post. Because off-the-rack construction allowed them to

\footnotetext{
${ }^{8}$ Some foreign brands are imported as brand garments, but many are produced locally under license. The C. Itoh trading company (and its apparel affiliate), for example, controls 19 brands which it sublicenses to a variety of firms. The Mario Valentino brand it sublicenses to 24 firms that produce 35 items under the label. The Beverly Hills Polo Club label it sublicenses to 21 firms to produce 30 items (Nihon sen'i 1995: 286).

${ }^{9}$ The figures for "other outlets" exclude convenience stores, as explained later. Note that not all merchandise passes through wholesaling channels.
} 
judge quality ex ante, it necessarily reduced the returns from a retailer's reputational capital. In the process, it opened the way for consumers to buy their suits from places without premium reputations.

Once consumers could judge construction quality before buying, the distribution of men's suits changed radically. The two firms that most successfully exploited the new opportunities were the Hiroshima-based Aoyama shoji and the Yokohama-based Aoki International. A variety of others like Konaka followed (see Table 3.4).

Aoyama opened its first store in 1974. By 1998, it had sales of 162 billion yen on 667 outlets. Aoki had 76 billion in sales on 281 outlets. Rather than locate in urban centers or at the major commuter line train terminals, these new firms opened outlets along suburban highways and roads. By doing so, they lowered their rent, and took advantage of the increased car ownership and modern highway networks.

Both Aoyama and Aoki specialized in basic business suits and related items (shirts, ties, and so forth). Combined with their multi-store network, this let them exploit scale economies in two dimensions. First, because business suits change only slowly, they have a relatively long shelf life. As a result, Aoyama and Aoki could place orders covering longer periods, and offer longer lead times. Those lead times, in turn, enabled manufacturers to handle Aoyama and Aoki's orders during slack days when their machinery would otherwise have been idle.

Second, because Aoyama and Aoki operated such large chains, they could consolidate orders across the country. The resulting larger lot sizes then enabled them to lower construction costs through the usual scale economies. For what they did to other firms in the sector as a result, Aoyama and Aoki earned the sobriquet "category killers."

What with larger lot orders and longer lead times, however, Aoyama and Aoki faced major business risks. Suits are expensive. As a result, a firm that orders them in quantities large enough to generate scale economies will necessarily gamble more capital than a firm generating comparable economies on undershirts. To control the resulting risk, Aoyama and Aoki needed accurate information about consumer preferences.

To obtain that information, Aoyama and Aoki integrated forward into retailing. They did not integrate to control "image," for their suits had no distinctive image to control. The firms themselves developed a reputation for selling sensible, reasonably priced suits, but that was an image they readily could have protected through contract rather than vertical integration. They did not integrate to protect relationship-specific investments. Their outlets presented little specific investments to protect. Other than firm-specific billboards, the outlets were much like any other nondescript if clean clothing outlet.

Instead, by integrating they obtained direct control over the personnel with the best access to information about consumer preferences. To be sure, a firm can obtain market information from independent retailers. A firm can also operate a few vertically integrated outlets and sell the rest of its output to independent retailers. In a variety of sectors, makers regularly choose such options. Aoyama and Aoki, however, found that they obtained more current and accurate information by controlling directly the entire retail operation.

As businessmen turned to these suburban chains for their basic suits, the department stores shifted their focus toward high-end, high-fashion suits. Granted, they still carry conservative ones similar to those of their suburban competitors. Yet the conservative suits at department stores are not cheap, and are not central to the 
store's focus. Tobu, for example, sold basic business suits for 50,000-70,000 yen, and crowded them into small areas.

By contrast Tobu generously allocated space to the fashion brands. Jackets at 70,000 yen and up (58,000 yen if in corduroy) and suits at 100,000 yen and up -- these it displayed prominently. For casual wear, a man could find a polyester fleece pullover from S.T. DuPont for 49,000 yen. For business occasions, he could buy a Dunhill suit at 140,000 yen, or an Armani at 170,000 yen. He could survey the offerings from Hickey-Freeman, Hugo Boss, or (the determinedly not high-fashion) Brooks Brothers. He could buy a Ferragamo sport coat for 320,000 yen, or Burberry's version of the raincoat well-dressed canon fodder wore into the trenches at Maginot for 175,000 yen. On another floor, he could cap the look with a Patek Philippe watch for 1.4 million yen or Blancpain at 1.6.

By contrast, at a suburban Tokyo Konaka outlet (runner-up to Aoyama-Aoki), a consumer could choose from among a large selection of business suits, but almost no designer labels. Around the corner from the Shimamura described earlier, for example, in October 2000 he would have found two floors of perhaps 300-400 square meters each. There, he would have paid 30,000 to 40,000 yen for a sport coat or 20,000 to 70,000 yen for a suit. He would also have found a wide variety of both on sale at half price. He could buy a fleece pullover at the more predictable 2,000 yen. A mile away at Ito Yokado, he could similarly have bought a suit for 30,000-50,000 yen, and found others at a further 50 percent discount. At Shimamura he would have found no suits, but could have picked up a wool sport coat for 5,800 yen. 
Table 3.4: Retail Sales of Men's Apparel

\begin{tabular}{lrc} 
& $\begin{array}{c}\text { Sales } \\
\text { (bil. y) }\end{array}$ & $\begin{array}{c}\text { Number } \\
\text { outlets }\end{array}$ \\
\hline Aoyama shoji & 162.2 & 667 \\
Aoki International & 76.2 & 281 \\
Konaka & 51.5 & 257 \\
Haruyama shoji & 49.5 & 221 \\
Takakyu & 32.3 & 230 \\
Mitsumine & 19.8 & 133 \\
Workman & 18.5 & 353 \\
Futata & 17.6 & 102 \\
Daisan shinshi fuku & 16.6 & 93 \\
Haruyama Chain & 16.3 & 110
\end{tabular}

\author{
Notes: Figures are for fiscal 1998. \\ Source: Nikkei ryutsu shimbun, Ryutsu keizai no \\ tebiki 2000 [2000 Handbook of the Economics of \\ Distribution] 211 (Tokyo: Nihon keizai shimbun, 1999).
}

\title{
3.2. Volatile Sectors
}

3.2.1 Young chic. Harajuku. At the same time that the department stores were losing men's business suit sales to Aoyama-Aoki, they were also losing sales in the most volatile sectors of the industry: the market for young women's apparel. As assiduously as they cultivated the high-fashion segment of the industry, the department stores had avoided the youth-market fringe. As consumer incomes rose, however, so did product-differentiation and the size of several fringe markets. By their inherent conservatism, the department stores had left unclaimed the market for the most aggressively trend-conscious. Out of the Harajuku section of Tokyo, several firms moved to capitalize on their "mistake."

At the close of the century, the most successful firms in the youth fringe were San'ei International and Five Foxes. Both firms had roots in Harajuku and its fashion industry, roots that antedated its current incarnation as hyper-chic promenade ground. At the time, the neighborhood was instead just the site of not-very-successful designers and apparel makers. Several of them (including the current San'ei and Five Foxes CEOs), were good friends and operated out the same building (the Laforet Harajuku). Through their friendship, they formed the Harajuku Apparel Council to promote the local industry. At one point they even fielded a city council candidate under the "Harajuku Fashion Party." Through their proximity, they eventually created the collective ambience that made Harajuku the hip capital it is today. 10

Both San'ei and Five Foxes ran specialty private label stores. Like Aoyama and Aoki, they used these stores to control the retail process. They valued that control,

\footnotetext{
${ }^{10}$ See www.hac.or.jp/v/vol-miyake.html (Nov. 2000).
} 
though, for two reasons very different from the reason the business suit makers valued it.

Repeat purchases. Because young women buy more apparel items per year than business men buy suits, firms in the youth market rely heavily on repeat purchases. As a result, they stand to capture large gains from cultivating brandspecific appeal. And cultivate it they do. Where Aoyama and Aoki offered generic white-collar uniforms, the youth-market stores invest heavily in brand-specific image. Toward that end, they directly control retail decor, staffing, marketing, and advertising.

Take San'ei International. The firm had begun as a wholesaler in the cosmetics industry. Determined to cultivate this cutting-edge image, it developed its own products and retail formula. Whether it opened its own stores or sold through department stores, it used similarly formulaic boutiques. When it moved into apparel, it sold its own labels, often in its own stores, and always through its consciously developed formula. By the late 1990s, it ran integrated apparel operations from design to retail. It placed its merchandise in a portfolio of 20 brands with elaborately choreographed images for each. It ran 600 retail outlets, employed 2,200 full-time workers, and earned sales of 61 billion yen.

Response time. On the cutting edge of fashion consumer preferences change at extraordinary speed. To respond, apparel makers depend crucially on information about day-to-day purchasing patterns. By controlling retail operations directly, firms in the youth market fringe could structure their sales process in a way that gave them that daily information. Aoyama and Aoki needed information too, but note the difference: Aoyama and Aoki needed it to mitigate the risks they bore by placing large-lot orders with long lead times; firms like San'ei needed it precisely because their lead times were so short. Like NASCAR, like apparel: "one thing you learn in racing," as Roger Penske put it, "is that they don't wait for you."

Crucially, both San'ei and Five Foxes used vertical integration not just for image but for speed. Founded in 1976, by the end of the 1990s Five Foxes had eclipsed San'ei with 123 billion in sales. Of that, it earned 40 percent on women's apparel, 26 percent on men's, and 25 percent on children's. It carried 5,000 full-time employees, owned 789 stores directly, and sold through another 200 outlets (e.g., franchised stores or department store counters) besides. Like San'ei, Five Foxes integrated wholesale and retail; not only did it run its own stores, it coordinated garment production (with 70 manufacturing firms) and used its own brands (e.g., Comme ça du Mode). Through that coordination, it could rapidly respond to changes in consumer buying patterns.

To facilitate the rapid shifts, several apparel makers (and not just those in the youth market) self-consciously adopted aspects of what the industry called a "quick response" (QR) system. Short-hand for an elaborate array of changes, many involving the use of computerized sales data, the system reached back to garment manufacturing (see Figure 3.1). Importantly, it did not reach further upstream. Instead, even the most nimble apparel makers used fabrics produced under long lead times and stockpiled until needed (Senken, 1999: 78-79, 172-73; Matsuo, 1996: 2829).

3.2.2 Cheap chic casual. -- In the market for office and weekend casual, Fast Retailing (the name says it all) similarly integrated wholesale with retail to cut 
response time (Ann. Rep.). The firm traced its origins to a 1949 Yamaguchi men's shop, but hit the winning formula in 1984 with its first Hiroshima "Uni-Qlo" store. From there, it boomed: 100 stores by 1994, 200 by 1996, 300 by 1997 . At the end of fiscal 1999, it owned 357 stores and ran another 11 by franchise. With 1,000 employees, it earned 111 billion yen in sales. "[K]haki casual is replacing the dark suits in which the Japanese marched out of poverty after World War II," Newsweek announced in November 2000 (Itoi, 2000: 16). If ever an announcement was as premature as Mark Twain's famous demise this was one, but more than anyone else the firm that profited from the (at least impending) end of the long march was UniQlo.

Like Aoyama and Aoki, Fast Retailing focused mostly on suburban outlets. But unlike them, it sold casual clothes for men, women, and children -- what it called "non-age uni-sex casual wear," and what others called Gap-clone. Uni-Qlo stood for "unique clothing warehouse," it told its shareholders in its 1999 annual report. Quality uniformity was part of its business strategy, declared Newsweek (Itoi, 2000: 17), for Uni-Qlo sold "the same products and service to anybody, anywhere and at any time." But so was rapid response to consumer demand. "In the past, what was fashionable in Tokyo was not necessarily fashionable in Osaka, let alone outside Japan," explained Uni-Qlo founder Tadashi Yanai (id., at 18). "There is no more time lag." To gain the necessary speed, Fast Retailing did what San'ei and Five Foxes did in Japan and what the Gap does in the U.S. it integrated the process from productplanning to wholesale to marketing to sales. 11

By the end of the 1990s, the formula generated enormous success. Given higher Gap prices, claimed one industry observer, every time a Uni-Qlo store opened near Gap, Gap lost 30 percent of its sales (id., at 19). Given its star quality, the Mitsukoshi, Tokyu, Matsuzakaya, and Sogo department stores were all vying for a Uni-Qlo boutique (id.).

\subsection{Between Suits and Fashion:}

3.3.1 The gains to diversified sales. Firms in the conservative sector of business suits integrate wholesale and retail. Firms in the volatile sector of young women's apparel integrate wholesale and retail. Firms in the new, mass-market casual sector integrate wholesale and retail. If firms in both conservative and volatile, high-priced and low-priced sectors integrate, why do not all firms do so? The short answer is that a vast expanse -- a vast market -- lies between Comme ça du mode and Uni-Qlo pullovers.

In apparel as in other markets, firms can economize through specialization and the division of labor. The best wholesalers are not always the best retailers, and vice versa. Rather than try to reach consumers itself, a wholesaler can often do better buying its retailing services on the market. Rather than try to buy from factories directly, a retailer can often do better buying wholesaling services on the market.

Put another way, firms choose between market and intra-firm transactions by relative gains and costs, and in many sectors of the apparel industry the gains from integration are small. ${ }^{12}$ In particular sub-markets, firms can indeed earn large gains

${ }^{11}$ See yahoo.marketguide.com/mgi/busidesc.asp?rt=busidescandrn=3677N (Nov. 2000). To monitor production more effectively, in 1997-98 it cut the number of factories with which it contracted (most were in China) by two-thirds. For the same reason, the next year it opened an office in Shanghai.

${ }^{12}$ Sometimes, argue observers, firms integrate to promote efficient levels of relationshipspecific investments. Perhaps they do, though we and others have argued that they exaggerate the real- 
from market information. Sometimes they can best obtain that informational advantage through vertical integration. Suppose an apparel maker can earn scaleeconomies through large investments of working capital. It may integrate to obtain an informational advantage that reduces the risks the investment entails. Suppose it faces an usually volatile market. It may integrate to obtain the information it needed to respond to sudden changes in consumer buying patterns.

Yet most apparel falls outside of those sectors. Dress shirts are relatively cheap. To make one efficiently, a firm need not invest anything close to the amounts it would need to generate scale economies in suit production. Neither do men's dress shirts change quickly. To meet market demand, a firm need not follow consumer buying patterns day-by-day. Much the same logic applies to socks, underwear, children's clothes, and most apparel for "mature" buyers (like the authors of this chapter).

3.3.2 Wholesaling only. Absent peculiar gains to vertical integration, an apparel maker will generally find that the standard gains from scope and scale economies point toward marketing its products broadly. By way of example, consider San'yo Shokai, a firm with fiscal 1999 sales of 136 billion yen (Ann. Rep.). It earned 27 percent of those sales on men's clothing, 58 percent on women's and children's, and 15 percent on accessories. It sold both to department stores and to other retailers. San'yo earned these massive sales on 2,000 employees. It could do so because it made nothing. Although nominally an apparel maker, it was in fact an apparel planner and buyer rather than a manufacturer.

San'yo shokai diversified across both consumer sex and retailer types. In turn, through this diversification it could exploit economies of scope that yielded economies of scale. To retailers, it could offer a wide variety of merchandise that varied by construction quality, by style, by target audience age, by target income. Through its marketing expertise, it effectively could assemble a full product line at low cost. In offering that product line, it thereby increased its attractiveness as a trading partner for retailers, and captured the larger order volumes that generated scale economies.

3.3.3 Manufacturing only. Contrast Wacoal, a company with fiscal 1999 sales of 138 billion yen (Wacoal, 1999; Ann. Rep.). Where San'yo bought what it sold from other factories, Wacoal manufactured almost everything in-house through its vast network of subsidiaries and affiliated corporations (16,000 employees, all told). Where San'yo offered a full range of apparel, Wacoal focused on underwear: in fiscal 1998, it had sales of 62 billion yen in foundation garments, 41 billion in lingerie, 12 billion in "personal wear" (e.g., robes), and 3 billion in "active wear" (sports wear).

Although it mostly sold only underwear and sleep-wear, within this sector Wacoal produced a wide variety. Whether bras or lingerie, it made a wide range for a wide range of retailers. As with San'yo, it could do so because of the economies of scope. The process was different, to be sure: San'yo could exploit its marketing expertise to assemble a broad range of products; Wacoal could exploit its manufacturing expertise to produce several varieties of underwear. In each case,

world significance of such investments (Casadesus-Masanell and Spulber, 2000; Miwa and Ramseyer, 2000a). Whatever the case in theory, no one claims firms make significant relationship-specific investments in apparel distribution. 
though, the firm gained by selling to a broad range of retailers. Through the resulting economies of scope, it captured large lot orders. Through the large order volumes, it generated manufacturing scale economies.

Wacoal was only one of many large specialty apparel manufacturers. For example, Fukusuke had fiscal 1999 sales of 68 billion, but 60 percent of it in socks. Its competitor Atsugi had sales of 38 billion yen, again mostly in socks and panty hose. Tsukamoto had sales of 46 billion, 30 percent of it in traditional garments like kimonos. Its competitor Ichida had 48 billion yen in sales, 39 percent in kimonos. Yamaki had sales of 22 billion yen, all in shirts, while its rival Tomiya Apparel had 28 billion yen in sales, 74 percent in shirts. And Tokyo Soir had 22 billion in sales too, but almost all in formal wear -- 65 percent of that black.

Firms in the underwear segment particularly gain by selling to broad range of retailers. Not only can they sell to the entire spectrum of apparel outlets from Tobu to Ito Yokado to Shimamura, they can also sell to the convenience stores. Besides food and drinks, these elaborate networks generally offer round-the-clock socks and underwear. Although they thus sell apparel, note that the number of apparel retailers given elsewhere in this chapter omit them. By government statistical custom, those numbers instead include only retailers for whom apparel sales are primary.

The wildly successful 7-11 franchise (50.7 percent owned by Ito Yokado) with 8,200 outlets, for example, stays open 24 hours a day. Suppose a harried mother of three awoke at 6:30 a.m. to find not only that she was out of milk but that she had forgotten to do the wash. While buying the milk at the 7-11 two blocks from home, she could pick up socks and underwear for her children besides.

3.3.4 Mixed wholesaling and manufacturing. Return, finally, to Onward Kashiyama with its 165 billion yen in fiscal 2000 sales (Ann. Rep.). Of those sales, Kashiyama earned 42 percent from men's apparel and 55 percent from women's and children's. Not only did it diversify by consumer sex, it also diversified across product and quality lines. For retailers, it offered both suits and sports wear for men, dresses and other garments for women. Some of this it manufactured in-house: e.g., suits, dresses -- 92 billion yen's worth in fiscal 2000. Others it bought already made: e.g., sports wear -- 40 billion yen's worth.

San'yo generated scope economies in marketing, Wacoal generated them in manufacturing, and Kashiyama generated them in both. Although the nature of the economies of scope differed, in each case the firm could transform them into scale economies. And to do so, in each case it needed to be able to sell its output to a broad range of retailers. Although the firms needed market information, to be sure, any informational advantage they might earn by bringing retail in-house would have cut their economies of scope.

\section{IMPLICATIONS}

American trade negotiators in the 1990s persistently claimed that Japanese distributional practices were inefficient, exclusionary, and opaque. Japanese bureaucrats were all-to-eager to agree. Yet the discussion above suggests that the existing practices followed a straightforward cost-based logic. That very logic suggests the practices were efficient and transparent; their mutability suggests they were not exclusionary.

Two further considerations point to the efficiency of those practices. First, the retail apparel market is highly competitive. Japanese consumers buy apparel from a wide variety of retailers $(183,600$ outlets, not counting department stores or 
convenience stores), and those retailers compete against each other fiercely. Necessarily, they leave little room for inefficient distributional practices -- for retailers who rely on inefficient wholesalers will regularly lose to those who do not.

The effects of the competition appear day to day, year to year. As Aoyama and Aoki boomed, Takakyu slid; as a few of the department stores grew, Sogo filed for bankruptcy, Tokyu closed its Nihonbashi store and Kintetsu stopped Tokyo operations. Among the smaller retailers, stores disappear regularly. Given this competition in the retail market, inefficient distributional patterns could persist only if retailers took their sources as given. The radical changes in sectors like men's suits, young women's apparel, and office casual, however, indicate they take them as anything but given.

Second, distribution margins are low. In Table 3.5, we compare wholesale and retail mark-ups in textiles for the U.S. and Japan. Crucially, the mark-ups in the two countries are remarkably close. For thread (for which we have a longer time series), the mark-up is slightly lower in Japan in the 1970s, and slightly higher in the 1990s. If they are high anywhere in Japan, moreover, they are not high among the multiple wholesale levels. They are high at retail.

Nevertheless, persistently critics point to the many levels through which a garment passes in Japan. Surely, they suggest, this multiplicity is inefficient. To demonstrate the point, they calculate total wholesale sales paid as a multiple of the retail sales (W/R), and show how much higher the Japanese ratio (W/R) is than elsewhere: 1.57 for France, 1.80 for West Germany, 1.87 for the U.S., and 2.03 for the U.K. -- and 4.24 for Japan (Miwa, 1991: 89; 1982 data except 1985 for Germany).

As a measure of distributional efficiency, however, the W/R ratio is irrelevant. Fundamentally, the ratio does not measure efficiency. It measures the extent of vertical integration. Posit two identical production channels. They use the have machines, employ the same quality and size work force, and generate the same sales and costs. In one channel, a single company owns all the factories, while in the other separate firms own each factory. Although the two channels have (by hypothesis) identical production efficiency, in the former the W/R ratio is low while in the latter it will be high. Or consider the automobile industry. Because Japanese automobile manufacturers use more subcontractors than American manufacturers, in the manufacturing process a Toyota will pass through more firms than a Chevrolet. If one calculated the W/R-equivalent for cars (total intermediate payments/retail price), the Toyota ratio would indeed be higher than the Chevrolet. Yet few observers would claim that GM's production is more efficient than Toyota's.

That innovative entrepreneurs like Aoyama and Fast Retailing can develop entirely new distribution channels similarly suggests apparel distribution is not exclusionary. The distributional system could plausibly exclude competitors -whether domestic or foreign -- only if innovators could not avoid it. Yet depending on the structure of consumer preferences they do avoid it.

Foreign firms regularly enter the apparel market, and sometimes they succeed. During the 1980s, high-end foreign brands sold enormously well in Japan. They sold so well that many abandoned their licensing arrangements for wholly or partially owned Japanese subsidiaries (what observers at the time called a "Japan boom," after the many new locally incorporated subsidiaries with names like "Georgio Armani Japan”). During the 1990s recession, middle-tier brands like Lands' End, L.L. Bean, and Benetton thrived too, but some of the fims on the high end continued to do well. By the end of the decade, Japan had become the largest market (30 percent of total 
sales) for Vuitton's “Celine” brand (Nikkei shimbun, Nov. 8, evening ed.). Vuitton itself was planning to build in Ginza it's largest store ever.

Suggestive evidence of the ease with which foreign producers can enter the market also appears in the way changes in relative costs affect import volumes. To illustrate the tie between costs and imports, in Figure 3.3 we track the response of textile imports to exchange rate fluctuations. The point is simple. As the costs of foreign apparel fell relative to Japanese apparel, consumers switched to foreign sources in massive numbers.

What of the complaints that Japanese distribution is opaque? Partly in response to American claims about opacity, the Ministry of International Trade and Industry declared that it would try to reduce (a) the use of free-returns and consignment sales arrangements; (b) the use of manufacturer-seconded employees in retail; and (c) the consummation of transactions on terms other than those in the written contract (Nihon sen'i 1992: 117-18). Given the straightforward cost-based rationale to the practices, $, 1,3$ find it hard to understand why anyone would think them anything but transparent. 14

Nonetheless, lawyers said they did. Persistently, they either found the practices hard to understand, or found it convenient to claim they did. So long as one used basic economic logic, Japanese distribution followed a predictable path. If lawyers really did find them opaque, maybe opacity too -- to mangle an aphorism hopelessly -- is in the eye of the beholder.

\footnotetext{
${ }^{13}$ We do not here discuss the logic to transactional terms deviating from written contracts. For an excellent analysis of the issue, see Bernstein (1996).

${ }^{14}$ Given that MITI also promised to try to reduce the use of volume rebates and discounts below manufacturer-suggested retail prices, efficiency and consumer welfare were obviously not what the negotiations were about.
} 
Table 3.5: Industry Mark-ups

A. Textiles

\begin{tabular}{|c|c|c|c|c|c|}
\hline Japan & & 1980 & 1985 & 1990 & 1995 \\
\hline \multirow[t]{3}{*}{ Total } & Mark-up & 51.10 & 53.08 & 53.52 & 52.73 \\
\hline & Wholesale & & & 13.09 & 14.16 \\
\hline & Retail & & & 39.34 & 30.66 \\
\hline
\end{tabular}

\begin{tabular}{rlrr} 
United States & 1982 & 1987 & 1992 \\
\hline Total Mark-up & 43.30 & 46.19 & 52.17 \\
Wholesale & & 6.96 \\
Retail & & & 44.82
\end{tabular}

B. Thread Only

\begin{tabular}{|c|c|c|c|c|c|c|c|c|c|}
\hline Japan & & 1960 & 1965 & 1970 & 1975 & 1980 & 1985 & 1990 & \\
\hline \multirow{3}{*}{ Total } & Mark-up & 24.6 & 31.1 & 30.0 & 33.5 & 41.2 & 40.3 & 40.5 & \\
\hline & Wholesale & & 11.6 & 11.4 & 12.0 & 13.4 & 11.6 & 11.6 & \\
\hline & Retail & & 19.5 & 18.6 & 21.5 & 27.8 & 28.7 & 28.9 & \\
\hline
\end{tabular}

\begin{tabular}{cccccccc} 
United States & 1693 & 1967 & 1972 & 1977 & 1982 & 1987 & 1992 \\
\hline Total Mark-up & 45.2 & 49.1 & 45.1 & 47.6 & 47.1 & 47.0 & 48.06
\end{tabular}

Notes: Total mark-up equals the total payments made by consumers in the industry, less the total payment received by the manufacturer, divided by total consumer payments, in percentages.

Wholesale and retail refer to the amount of Total mark-up received by retailers and wholesalers respectively. Wholesale and retail together do not sum to the "total" because of the omitted transportation sector.

Source: See Nishimura, Tachibana and Tsubouchi (this volume), Table 2.3 . 
Figure 1.4: Imports and Exchange Rates

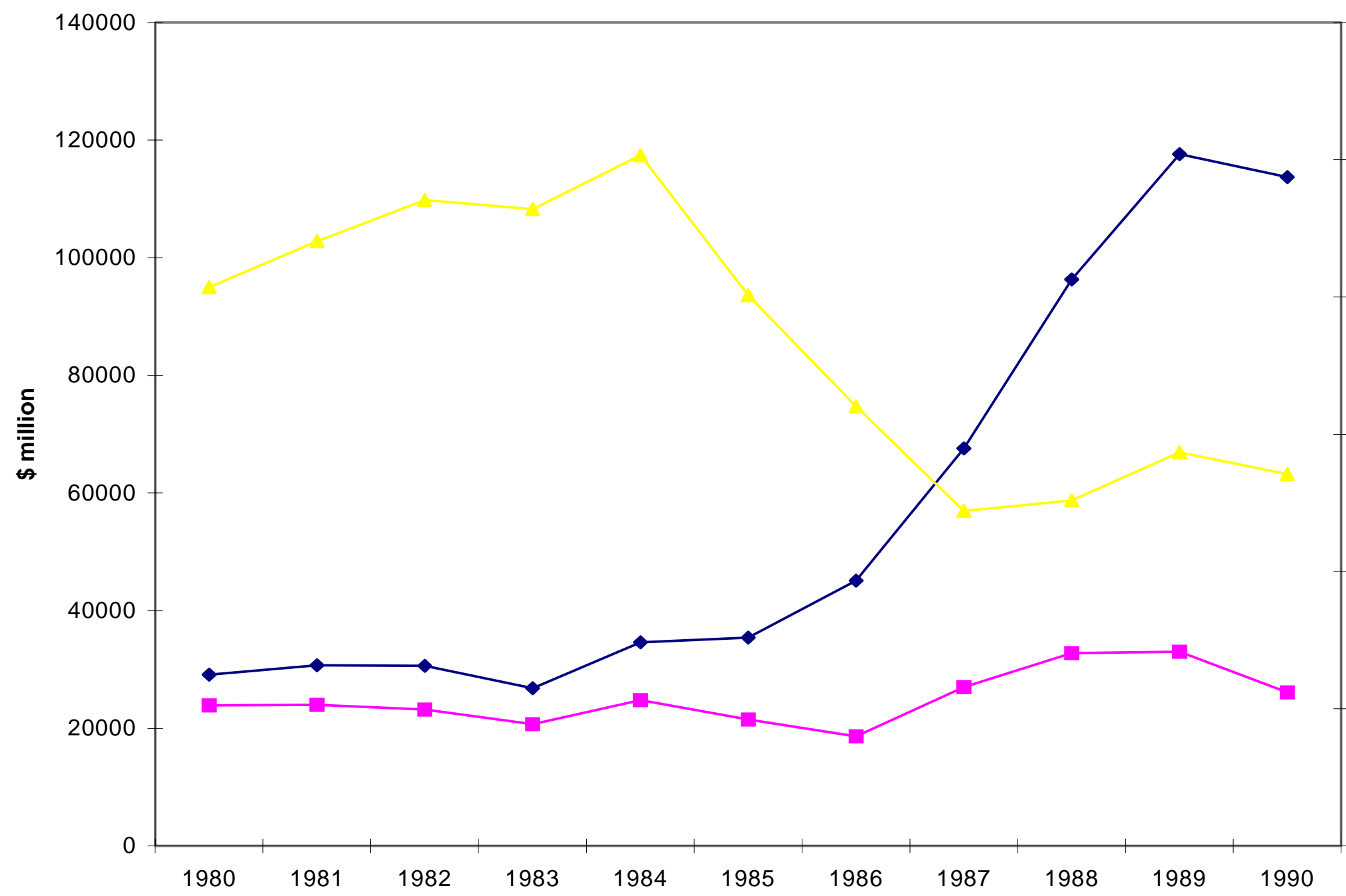

Source: Nihon sen'i shimbun sha, ed., Sen'i fasshon nenkan [Textiles, Fashion Annual] 76 (Tokyo: Nihon sen'i shimbun sha, 1992). 


\section{CONCLUSION}

Factories, brokers, importers, wholesalers, retailers -- the Japanese apparel industry presents an apparently bewildering array. Instead of a few big firms, it presents many small. Instead of integrated operations, it presents cross-market contracts. Instead of routinized long-term relations, it presents ties in flux.

As chaos, however, this is deceptive chaos. The way firms organize and reorganize, negotiate and renegotiate follows simple economic principles. Largely, they do so by a logic that tracks access to information, scale and scope economies, and incentives to economize. Largely, the result is an industry in flux, but in predictable flux. It is an industry where firms pick organizational and contractual structures that maximize their competitive advantage. It is an industry that firms enter and leave as they gain and lose competitive advantage. Like most industries, it is an industry where firms pursue efficient arrangements or die. 


\section{References}

Bernstein, Lisa. 1996. "Merchant Law in a Merchant Court: Rethinking the Code's Search for Immanent Business Norms." University of Pennsylvania Law Review, 144: 1765.

Casadesus-Masanell, Ramon and Daniel F. Spulber. 2000. "The Fable of Fisher Body." Journal of Law and Economics, 43: 67.

Depaato nyusu sha, ed. 1999. Hyakkaten chosa nenkan [Department Store Annual]. Tokyo: Depaato nyusu sha.

Hankyu hyakkaten, ed. 1998. Kabushiki kaisha Hankyu hyakkaten [Fifty-Year History of Hankyu Department Store, Inc.]. Osaka: Hankyu hyakkaten.

Hashimoto, Juro and Shuzo Koyama. 1991. Sezon no rekishi [A History of Saison]. Tokyo: Libro port.

Itoh, Motoshige. 1994. "The Japanese Wool Product Industry." In Christopher Findley and Motoshige Itoh, eds., Wool in Japan: Structural Change in the Textile and Clothing Market, 13-27. Pymble, Australia: HarperEducational Publishers.

Itoi, Kay. 2000. “Dress Down for Success.” Newsweek (Asia ed.), Nov. 13, 2000, at 16.

K.K. Wacoal, ed. 1999. Wakoru 50-nen shi -- shiryo shu [Wacoal: A Fifty-Year History -- Materials]. Kyoto: Wacoal.

Matsuo, Takeyuki, ed. 1999. Apareru gyokai hando bukku [Apparel Industry Handbook]. Tokyo: Toyo keizai shimpo sha.

Miwa, Yoshiro and J. Mark Ramseyer. 2000a. "Rethinking Relationship-Specific Investments: Subcontracting in the Japanese Automobile Industry." Michigan Law Review, 98: xx.

Miwa, Yoshiro and J. Mark Ramseyer. 2000b. The Value of Prominent Directors: Lessons in Corporate Governance from Transitional Japan. Unpublished manuscript.

Miwa, Yoshiro. 1994. "The Retail Market for Wool Products: The Case of Men's Suits in Japan." In Christopher Findley and Motoshige Itoh, eds., Wool in Japan: Structural Change in the Textile and Clothing Market, 28-43. Pymble, Australia: HarperEducational Publishers.

Nihon sen'i shimbun sha, ed. Various years. Sen'i fasshon nenkan [Textiles, Fashion Annual]. Tokyo: Nihon sen'i shimbun sha.

Nihon tokei kyokai, ed. 1987. Nihon choki tokei soran [Historical Statistics of Japan]. Tokyo: Nihon tokei kyoku. 
Nikkei ryutsu shimbun. 1993. Ryutsu gendai shi [A History of Modern Distribution]. Tokyo: Nihon keizai shimbun.

Nikkei ryutsu shimbun. 1999. Ryutsu keizai no tebiki 2000 [2000 Handbook of the Economics of Distribution]. Tokyo: Nihon keizai shimbun.

Sen'i kogyo kozo kaizen jigyo kyokai. 1990. Sen'i sangyo ni okeru gyoshu betsu torihiki tekiseika shishin shu [Directions for Improving Transactions in the Textile Industry, by Sector].

Senken shimbun sha, ed. 1999. Yoku wakaru apareru gyokai [Easy to Understand -The Apparel Industry]. Tokyo: Nihon jitsugyo shuppan sha, rev. ed.

Somu cho, ed. 2000. Nihon tokei nenkan [Japan Statistical Yearbook]. Nihon tokei kyoku.

Annual Reports (Yuka shoken hokoku sho soran):

K.K. Onwaado kashiyama (No. 19-31; 2000).

K.K. Fuaasuto riteiringu (No. 19-226; 1999).

K.K. Wakoru (No. 5-65; 2000).

K.K. San'yo shokai (No. 19-109; 1999). 